\title{
PERUBAHAN FISIOLOGIS DAN BIOKIMIA BENIH TENGKAWANG SELAMA PENYIMPANAN
}

\author{
Physiological and Biochemical Changes of Tengkawang Seeds During Storage Period
}

\author{
Asep Rohandi ${ }^{1} \&$ Nurin Widyani ${ }^{2}$ \\ ${ }^{1}$ Balai Penelitian Teknologi Agroforestry, Jl. Raya Ciamis - Banjar Km. 4, 46201 Ciamis, \\ Telp. (0265) 771352 Fax. (0265) 775866, Email : seps.grt@gmail.com \\ ${ }^{2}$ Balai Penelitian Teknologi Perbenihan Tanaman Hutan, Jl. Pakuan Ciheuleut PO. Box 105 Bogor 16001 \\ Telp./Fax : (0251) 327768
}

Diterima : 12 Mei 2016, direvisi : 22 Juni 2016, disetujui : 26 Juli 2016

\begin{abstract}
ABSTRAK
Penelitian ini bertujuan untuk menganalisis aspek fisiologi dan biokimia perubahan fisik dan fisiologis benih tengkawang (Shorea stenoptera) selama proses penyimpanan. Percobaan penyimpanan dilakukan dengan menggunakan rancangan acak lengkap (RAL) faktorial 2 x 5 dengan 3 kali ulangan. Faktor-faktor tersebut meliputi suhu ruang simpan dan lama penyimpanan. Suhu ruang simpan terdiri dari ruang kamar $\left(28-29^{\circ} \mathrm{C}\right)$ dan ruang $\mathrm{AC}\left(18-20{ }^{\circ} \mathrm{C}\right)$, sedangkan lama penyimpanan terdiri dari 0, 1, 2, 3 dan 4 minggu. Parameter fisiologis yang diamati meliputi daya berkecambah, kecepatan berkecambah dan nilai perkecambahan, sedangkan parameter biokimia meliputi kandungan pati, lemak, protein dan daya hantar listrik. Hasil penelitian menunjukkan bahwa perlakuan lama penyimpanan memberikan pengaruh sangat nyata terhadap perubahan fisiologis (daya berkecambah, kecepatan berkecambah dan nilai perkecambahan) benih $S$. Stenoptera, yang dapat menyebabkan viabilitas benih terus menurun dengan semakin lamanya periode penyimpanan. Perbedaan suhu ruang simpan pada penyimpanan benih tengkawang (KA awal 46,06\%) tidak menunjukkan perbedaan nyata. Sampai minggu ke 4 daya berkecambah benih di ruang kamar mampu dipertahankan sebesar $44 \%$ dan di ruang AC sebesar 49,33\%. Kandungan lemak dan nilai daya hantar listrik cenderung mengalami peningkatan, sedangkan kandungan pati dan protein pada benih tengkawang cenderung mengalami penurunan selama penyimpanan.
\end{abstract}

Kata kunci : biokimia, fisiologis, perubahan, penyimpanan, tengkawang

\section{ABSTRACT}

This research aimed to analyze physiological and biochemical changes of tengkawang (S. stenoptera) seeds during storage process. The experimental design used $2 \times 5$ factorial in completely randomized design with 3 replications. These factors consisted of storage temperatures (ambient room $\left(28-29^{\circ} \mathrm{C}\right.$ ) and $\mathrm{AC}$-room $\left(18-20^{\circ} \mathrm{C}\right)$ ) and periods of storage $(0,1,2,3$ and 4 weeks). The parameters of physiological observation were germination rate, germination speed and germination value, whereas parameters of biochemistry were starch, fat and protein contents, as well as leachate conductivity. The results showed that the differences in storage period treatments significantly affect physiological changes of tengkawang seeds, in which seed viability continued to decline with the increasing length of storage period. Meanwhile, storage temperatures did not have a significant effect on physiological and biochemical changes of tengkawang seeds. Tengkawang seeds with moisture content 46,06\% could maintain the germination rate up to 44,00\% in ambient room and 49,33\% in AC-room until 4 weeks. Fat content and leachate conductivity values tend to increase, while starch and protein contents in tengkawang seeds have a tendency to decrease during storage period.

Keywords : biochemical, physiological, change, storage, tengkawang

\section{PENDAHULUAN}

Tengkawang (S. stenoptera) disebut juga sebagai meranti merah termasuk ke dalam famili Dipterocarpaceae. Daerah penyebaran jenis ini adalah di Sumatera, Kalimantan dan Maluku. Tinggi pohon dapat mencapai $50 \mathrm{~m}$, panjang batang bebas cabang sampai $30 \mathrm{~m}$, diameter umumnya sekitar $100 \mathrm{~cm}$ (Martawijaya et.al. 1989). Tengkawang merupakan salah satu jenis tanaman kehutanan yang tumbuh di hutan hujan tropika.
Keberadaan jenis ini di habitat alaminya saat ini mulai berkurang dan sulit ditemukan (Istomo dan Hidayati, 2010).

Penanaman jenis tengkawang sering terkendala terutama dalam penyediaan benih dengan jumlah cukup dan bermutu karena siklus berbunga dan berbuah yang tidak teratur. Benih tengkawang yang merupakan jenis rekalsitran mempunyai kemampuan hidup sangat pendek terutama apabila disimpan pada udara terbuka (Umrani et al., 
2015). Usaha penyimpanan dalam waktu lama belum berhasil dilakukan karena benih tengkawang cepat mengalami kemunduran (menurun viabilitasnya) (Purwaningsih, 1999). Kondisi tersebut sangat tidak menguntungkan karena pada kadar air tertentu yang relatif tinggi benih akan cepat berakar dan viabilitasnya akan cepat mengalami kemunduran sehingga mutunya menjadi sangat rendah. Berdasarkan karakteristik tersebut, diperlukan penanganan khusus untuk mempertahankan viabilitas dan vigor benih selama penyimpanan (Lodong et al., 2015) ataupun pengiriman (Maemunah dan Adelina, 2009).

Kerusakan benih merupakan proses terpisah dari perkembangan dan perkecambahan benih. Penurunan kualitas benih terjadi selama pelapukan di lapangan, pemanenan dan penyimpanan (Mahjabin et al., 2015). Kemunduran benih dapat ditinjau dari aspek fisiologi dan biokimia. Indikasi fisiologi kemunduran benih antara lain penurunan daya berkecambah dan vigor. Selama penyimpanan, benih akan mengalami penuaan dan kemunduran (deteriorasi). Indikasi biokimia kemunduran benih dicirikan antara lain penurunan aktivitas enzim, penurunan cadangan makanan dan meningkatnya nilai konduktivitas. Benih yang 'mundur', kecepatan respirasinya meningkat sehingga menyebabkan pengurangan cadangan makanan, akumulasi metabolit hasil perombakan cadangan makanan, dan dapat menyebabkan 'kelaparan' pada jaringan meristem. Selama penyimpanan, benih akan mengalami penuaan dan kemunduran (deteriorasi). Mahjabin et al., (2015) menjelaskan bahwa selama penyimpanan, kadar air benih dan suhu bertanggung jawab terhadap kerusakan benih.

Berdasarkan kondisi di atas, penelitian tentang semua perubahan yang terjadi baik dari aspek fisiologis dan biokimia benih selama penyimpanan sangat penting untuk dilakukan. Penelitian ini bertujuan untuk mengetahui pengaruh ruang simpan dan periode penyimpanan terhadap perubahan fisiologis dan biokimia benih tengkawang $(S$. stenoptera). Hasil dari penelitian ini diharapkan dapat ditemukannya teknik penyimpanan secara tepat untuk memperpanjang daya simpan benih tengkawang.

\section{METODOLOGI PENELITIAN}

\section{A. Lokasi dan Waktu}

Pengumpulan buah tengkawang ( $S$. stenoptera) dilakukan di Kebun Percobaan Pasirhantap, Sukabumi. Lokasi kebun percobaan berada pada ketinggian $600 \mathrm{mdpl}$ dan memiliki topografi yang termasuk punggung bukit bergelombang dengan jenis tanah Latosol. Klasifikasi iklim termasuk pada tipe B (Schmidt dan Ferguson).

Penelitian dilaksanakan di

Laboratorium Balai Penelitian Teknologi Perbenihan (BPTP) dan Laboratorium Ekofisiologi Balai Penelitian Tanaman Rempah dan Obat (Balitro), Bogor.

\section{B. Bahan dan Peralatan}

Bahan yang digunakan adalah benih $S$. stenoptera, media perkecambahan, kertas aluminium foil, polybag dan lain-lain. Alatalat yang digunakan terdiri dari peralatan laboratorium dan peralatan rumah kaca. Peralatan laboratorium meliputi alat gelas, alat perkecambahan, pengukuran kadar air, desikator, wadah penyimpanan (kardus), ruang simpan, peralatan analisa biokimia dan lainlain. Peralatan rumah kaca meliputi bak perkecambahan, pengukur suhu dan lain-lain.

\section{Metode Penelitian}

1. Pengumpulan buah, ekstraksi dan seleksi benih

Pengunduhan buah $S$. stenoptera dilakukan pada buah yang berwarna coklat mengkilap yang diambil dengan sayapnya untuk mengurangi terjadinya pengeringan. Buah diekstraksi dengan cara memisahkan sayapnya dari benih, dan diseleksi dengan membuang benih busuk, terserang hama, jamur, benih hampa serta luka mekanis. Seleksi benih $S$. stenoptera dilakukan dengan cara memotong bagian pada benih berbentuk sayap sebelum diberikan perlakuan.

\section{Penyimpanan Benih}

Setelah dilakukan seleksi terhadap benih, maka dilakukan penyimpanan benih sesuai dengan perlakuan yang diberikan. Tahapan kegiatan penyimpanan tersebut secara rinci adalah sebagai berikut : 
a. Benih yang digunakan sebanyak 30 buah untuk setiap wadah yang terdiri dari 25 buah untuk perkecambahan, 2 buah untuk pengukuran kadar air dan 3 buah untuk pengujian biokimia. Pembagian benih dilakukan secara acak.

b. Benih diukur kadar air dan kandungan biokimianya sebelum dan sesudah dilakukan penyimpanan.

c. Serbuk gergaji dimasukan ke dalam wadah simpan.

d. Benih diletakkan dalam wadah penyimpanan yang telah diisi dengan media simpan (serbuk gergaji) sebanyak 30 benih setiap wadah untuk pengujian kadar air, perkecambahan dan biokimia.

e. Wadah simpan ditutup dan dimasukkan ke ruang simpan sesuai dengan perlakuan yang diberikan.

f. Pengujian perkecambahan dilakukan pada media campuran pasir : tanah $(1: 1)$.

\section{Rancangan Percobaan}

Percobaan penyimpanan dilakukan dengan menggunakan rancangan acak lengkap (RAL) faktorial $2 \times 5$ dengan 3 kali ulangan. Faktor-faktor tersebut meliputi A (ruang simpan) dan B (lama penyimpanan) yang secara rinci adalah sebagai berikut :

Faktor A : Ruang simpan yang terdiri dari ruang kamar $\left(28-29^{\circ} \mathrm{C}\right)$ dan ruang $\mathrm{AC}\left(18-20^{\circ} \mathrm{C}\right)$.

Faktor B : Lama penyimpanan adalah $0,1,2,3$ dan 4 minggu.

Setiap unit perlakuan terdiri dari 25 benih ditambah 2 benih untuk pengukuran kadar air dan 3 benih untuk pengujian biokimia. Matrik percobaan seperti disajikan pada Tabel 1 .

Tabel 1. Matrik perlakuan percobaan

Table 1.Matrix of experimental treatments

\begin{tabular}{|c|c|c|c|c|c|}
\hline \multirow{2}{*}{ Faktor A } & \multicolumn{5}{|c|}{ Faktor B } \\
\hline & B0 & B1 & B2 & B3 & B4 \\
\hline $\mathrm{A} 1\left(28-29^{0} \mathrm{C}\right)$ & A1B0 & A1B1 & A1B2 & A1B3 & A1B4 \\
\hline $\mathrm{A} 2\left(18-20^{\circ} \mathrm{C}\right)$ & A2B0 & A2B1 & A2B2 & A2B3 & A2B4 \\
\hline
\end{tabular}

\section{E. Teknik Pengumpulan Data}

Data yang diamati dalam penelitian ini meliputi parameter fisiologis dan biokimia benih. Parameter fisiologis meliputi pengukuran kadar air, daya berkecambah, kecepatan berkecambah, dan nilai perkecambahan. Selain parameter fisiologis, analisa juga dilakukan untuk mengetahui biokimia benih meliputi kandungan lemak, pati, total protein dan daya hantar listrik. Pengamatan pertumbuhan benih $S$. stenoptera dilakukan setiap dua hari sekali selama 90 hari (3 bulan), sedangkan untuk pengamatan biokimia benih dilakukan secara bertahap sesuai dengan perlakuan yang diberikan. Analisis biokimia benih dilakukan di laboratorium Ekofisiologi Balai Penelitian Tanaman Rempah dan Obat (Balitro), Bogor.

Pengukuran kadar air benih dilakukan dengan menggunakan 2 buah contoh benih untuk setiap perlakuan dan dilakukan dalam dua tahap. Tahap pertama merupakan tahap pra pengeringan (predrying). Pada tahap ini benih ditimbang sehingga diperoleh berat basah, propagul kemudian dimasukkan ke dalam oven dengan suhu $130^{\circ} \mathrm{C}$ selama 5-10 menit (ISTA, 1985). Setelah dimasukkan ke dalam desikator selama 45 menit, benih ditimbang lagi sehingga diperoleh berat kering. Pada tahap kedua, sebelum dimasukkan ke oven, benih dipotong dan dibelah. Suhu oven yang digunakan adalah $105^{\circ} \mathrm{C}$ selama 17 jam. Berat kering diperoleh dengan cara menimbang benih setelah dibiarkan dalam desikator selama 45 menit.

Kadar air dihitung berdasarkan rumus yang terdapat dalam ISTA (2006) yaitu :

$$
\mathrm{MC}=\mathrm{S} 1+\mathrm{S} 2-\frac{\mathrm{S} 1+\mathrm{S} 2}{100}
$$

Keterangan :

MC : Kadar air dalam \%

S1 : Jumlah air yang hilang pada pemanasan predrying $(\%)$

S2 : Jumlah air yang hilang pada pemanasan kedua (\%) 
Daya berkecambah (DB) yaitu banyaknya persentase kecambah normal pada pengamatan selama 30 hari setelah tanam (hst), dengan persamaan sebagai berikut (Sutopo, 2002) :

Daya Berkecambah $(\%)=\frac{\text { Jumlah kecambah normal }}{\text { Total benih yang ditabur }} \times 100 \%$

Kecepatan berkecambah (KT) diukur berdasarkan total nilai pertambahan kecambah normal setiap hari, dengan persamaan :

$$
\mathrm{KT}(\% / \text { hari })=\frac{\mathrm{N} 1}{\mathrm{D} 1}+\frac{\mathrm{N} 2}{\mathrm{D} 2}+\ldots \ldots \ldots+\frac{\mathrm{Nn}}{\mathrm{Dn}}
$$

\section{Keterangan :}

KcT : kecepatan perkecambahan

N1......Nn : kecepatan normal pada $1,2, \ldots . ., \mathrm{n}$ hari setalah tanam (\%)

D1........Dn : jumlah hari setelah tanam

Nilai perkecambahan (NP) dihitung dengan menggunakan rumus adalah :

$$
\begin{gathered}
\text { GV }=\text { PV x FGD } \\
\text { PV }=\frac{\% \text { Perkecambahan puncak }}{\text { Jumlah hari perkecambahan }}
\end{gathered}
$$

$\mathrm{FGD}=\frac{\% \text { Perkecambahan pada akhir pengamatan }}{\text { Jumlah hari uji }}$

Keterangan :

NP : Nilai Perkecambahan

PV : Perkecambahan Puncak

FGD : Perkecambahan harian akhir

\section{E. Teknik Pengumpulan Data}

Data pengamatan dianalisis dengan menggunakan analisis ragam (ANOVA) untuk mengetahui perbedaan respon tanaman yang diberi perlakuan ruang simpan dan periode simpan serta interaksi antar perlakuan. Jika perlakuan berpengaruh nyata dilanjutkan dengan uji Duncan Multiple Range Test (DMRT) pada $\alpha 0,05$.

\section{HASIL DAN PEMBAHASAN}

Hasil analisis keragaman menunjukkan bahwa pemberian faktor tunggal ruang simpan (A) dan lamanya penyimpanan (B) serta interaksi dari kedua faktor tersebut berpengaruh sangat nyata $(p<0,01)$ untuk parameter daya berkecambah (DB) dan Kecepatan Tumbuh (KT). Pemberian faktor tunggal A serta interaksi A dan B berpengaruh tidak nyata untuk parameter kadar air (KA) dan nilai perkecambahan (NP), sedangkan pemberian faktor tunggal $\mathrm{B}$ berpengaruh nyata untuk parameter KA dan sangat nyata untuk parameter NP (Tabel 2).

Daya berkecambah benih $S$. stenoptera pada penyimpanan di ruang AC sampai akhir pengamatan (4 minggu) tidak berbeda nyata dengan penyimpanan di ruang kamar (Tabel 3). Demikian juga dengan laju penurunan kadar air benih pada kedua ruang simpan tersebut tidak menunjukkan pengaruh yang berbeda nyata. Hal ini diduga disebabkan oleh karakter kulit benih tengkawang yang cukup keras sehingga kondisi lingkungan berpengaruh relatif lambat terhadap penurunan kadar air benih yang menyebabkan terhambatnya proses penurunan kadar air benih. Meskipun demikian, laju penurunan daya berkecambah benih pada ruang kamar lebih cepat dibandingkan pada ruang AC.

Tabel 2. Rekapitulasi hasil analisis keragaman pengaruh penyimpanan terhadap parameter kadar air $(\Omega A)$ daya berkecambah (DB), kecepatan berkecambah (KT) dan nilai perkecambahan (NP) benih $S$. Stenoptera

Table 2. Summarized analysis of variance regarding the effect of storage on the moisture content, germination percentage, germination rate and germination value of $\mathrm{S}$. stenoptera seeds

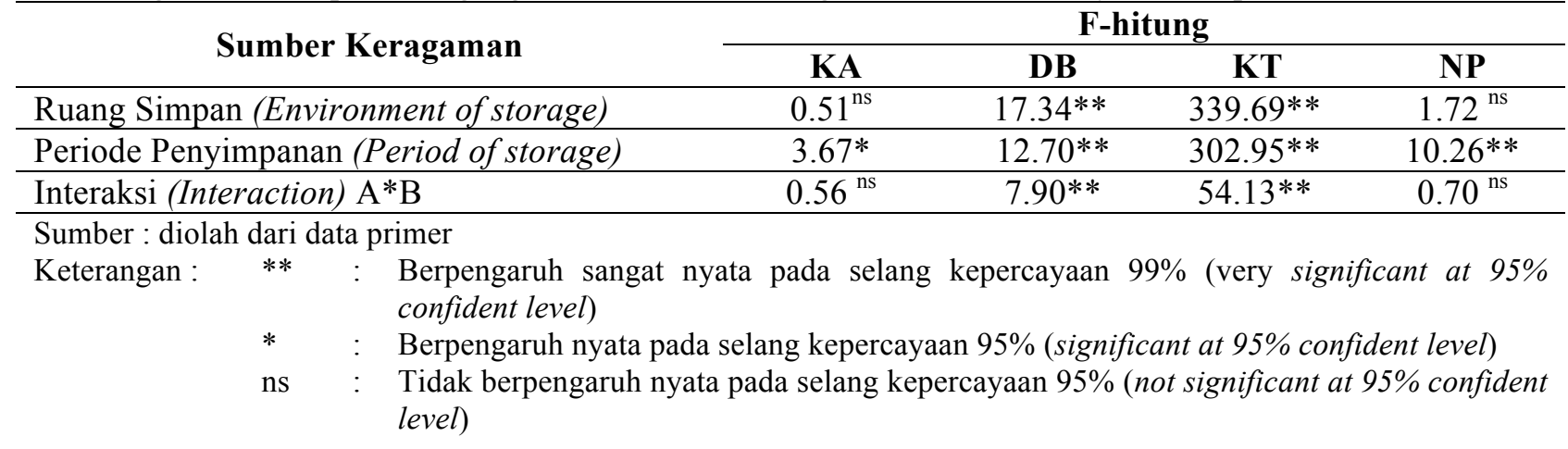


Selama penyimpanan 4 minggu terjadi penurunan daya berkecambah sebesar $41,33 \%$ pada ruang kamar dan $26,67 \%$ pada ruang AC, meskipun demikian pada akhir pengamatan (selama 4 minggu) benih tengkawang belum mengalami kematian (tidak berkecambah). Kondisi demikian juga terjadi pada benih eboni (Yuniarti et al., 2013), yang menunjukkan bahwa penyimpanan pada ruang AC mampu mempertahankan viabilitas benih lebih baik dibandingkan ruang kamar ataupun refrigator. Zanzibar (2011) menyebutkan bahwa penyimpanan benih tusam (Pinus merkusii) pada suhu kamar sangat mempercepat laju kemunduran benih. Samjaya et al. (2010) dalam Sulaiman et al. (2010) menyebutkan bahwa penurunan kadar air berhubungan dengan tingginya laju respirasi dan penguapan. Pada kondisi demikian, benih masih mampu melakukan proses metabolisme untuk mempertahankan viabilitasnya. Hasil penelitian Rohandi dan Widyani (2011) menunjukkan bahwa kadar air kritis untuk jenis tengkawang (S. Stenoptera) diperkirakan pada tingkat kadar air 15\% dan pada kadar air $8 \%$ benih sudah tidak mampu lagi berkecambah. Hasil uji jarak Duncan penyimpanan benih $S$. stenoptera pada berbagai perlakuan selengkapnya dapat dilihat pada Tabel 3 .

Tabel 3. Hasil uji jarak duncan pengaruh penyimpanan terhadap parameter daya berkecambah (DB) dan kecepatan berkecambah (KT) jenis S. stenoptera

Table 3. Summarized of Duncan's multiple range test to the effect of storage on the moisture content, germination percentage, germination rate and germination value of $\mathrm{S}$. stenoptera seeds

\begin{tabular}{cccc}
\hline \multirow{2}{*}{ No. } & Perlakuan & \multicolumn{2}{c}{ Parameter } \\
\cline { 2 - 4 } & & $\begin{array}{c}\text { Daya Berkecambah } \\
\mathbf{( \% )}\end{array}$ & $\begin{array}{c}\text { Kecepatan Berkecambah } \\
\text { (\% per etmal) }\end{array}$ \\
\hline 1. & A1B0 & $85.33 \mathrm{a}$ & $2.65 \mathrm{a}$ \\
\hline 2. & A1B1 & $62.67 \mathrm{bc}$ & $1.35 \mathrm{~cd}$ \\
\hline 3. & A1B2 & $48.00 \mathrm{~cd}$ & $1.20 \mathrm{de}$ \\
\hline 4. & A1B3 & $44.00 \mathrm{~d}$ & $0.23 \mathrm{~g}$ \\
\hline 5. & A1B4 & $44.00 \mathrm{~d}$ & $1.65 \mathrm{bc}$ \\
\hline 6. & A2B0 & $85.33 \mathrm{a}$ & $2.65 \mathrm{a}$ \\
\hline 7. & A2B1 & $76.00 \mathrm{ab}$ & $1.81 \mathrm{~b}$ \\
\hline 8. & A2B2 & $49.33 \mathrm{~cd}$ & $0.76 \mathrm{f}$ \\
\hline 9. & A2B3 & $46.66 \mathrm{~d}$ & $0.99 \mathrm{ef}$ \\
\hline 10. & A2B & $49.33 \mathrm{~cd}$ & $0.91 \mathrm{ef}$ \\
\hline
\end{tabular}

Sumber : diolah dari data primer

Keterangan (Remarks) : A : Ruang simpan (1 : ruang kamar; 2 : ruang AC), B : Lama penyimpanan (0 : tanpa penyimpanan; $1: 1$ minggu; $2: 2$ minggu; $3: 3$ minggu; $4: 4$ minggu)

Angka-angka yang diikuti oleh huruf yang sama pada kolom yang sama tidak berbeda nyata pada tingkat kepercayaan $95 \%$ uji berganda Duncan (values followed by the same letters in the same column are not significantly different at 95\% confident level in accordance to the Duncan's multiple range test)

Kadar air benih dipengaruhi nyata oleh faktor lamanya waktu penyimpanan dan hal tersebut berpengaruh terhadap nilai perkecambahan (NP) (Gambar 1). Kadar air benih tidak berbeda nyata sampai penyimpanan 2 minggu dan menurun secara nyata pada penyimpanan 3 dan 4 minggu. Selama waktu penyimpanan 4 minggu, kadar air benih menurun sebesar $17,05 \%$ pada ruang kamar dan $15,1 \%$ pada rang AC. Sementara itu, daya berkecambah menurun $41,33 \%$ pada ruang kamar dan $36 \%$ pada ruang AC.
Penurunan kadar air merupakan faktor penyebab terjadinya kemunduran benih rekalsitran (Tresniawati et al., 2014). Penurunan kadar air selama penyimpanan merupakan faktor kritis yang mempengaruhi viabilitas benih (Sukesh and Chandrashekar, 2013). Penurunan daya kecambah akibat penurunan kadar air juga dilaporkan pada benih Agathis damara (Djaman et al., 2006), Rhizophora apiculata (Rohandi dan Widyani, 2010) dan kemiri sunan (Reutealis risperma) (Tresniawati et al., 2014). 


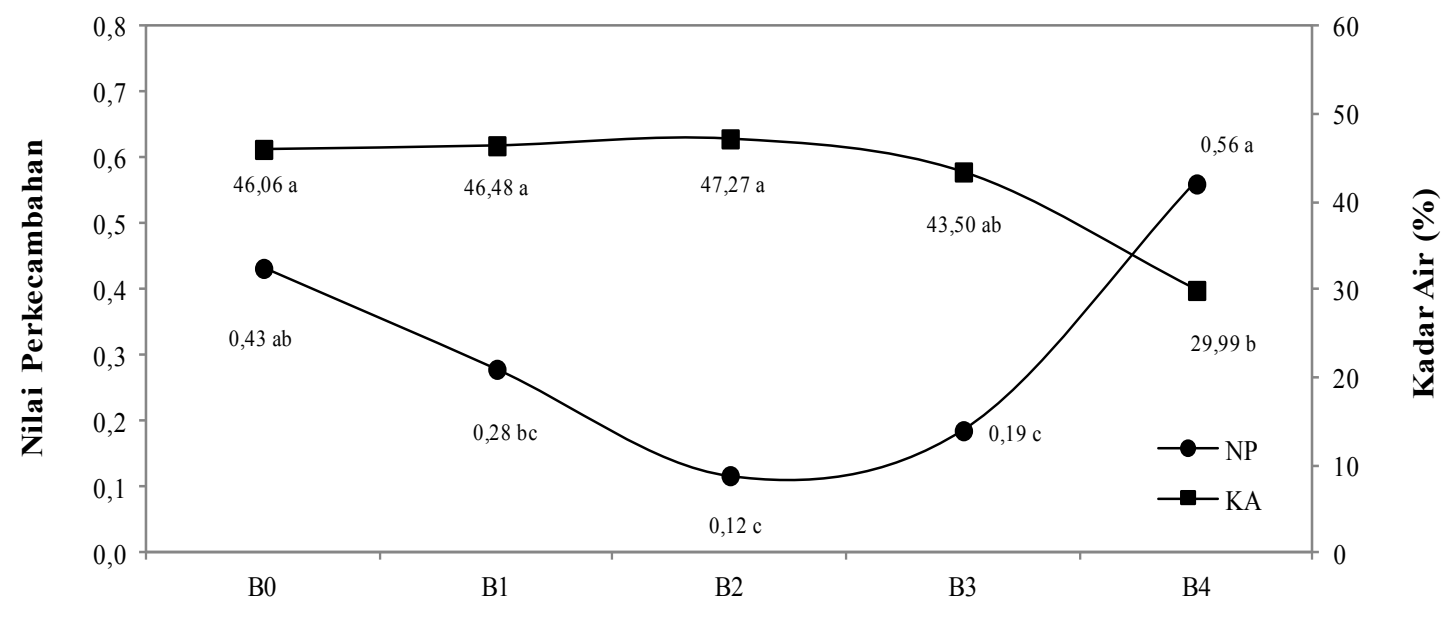

Lama Penyimpanan (minggu)

Gambar 1. Kadar air (KA) dan nilai perkecambahan (NP) benih tengkawang dengan perbedaan lama penyimpanan.

Figure 1. Moisture content $(M C)$ and germination value $(G V)$ of S. stenoptera seed at differences of storage duration

Suhu dan kadar air benih berperan sangat penting dan fundamental dalam menentukan status viabilitas benih selama penyimpanan (Khrisnan et al. 2005). Kadar air benih pada akhir periode simpan merupakan faktor yang sangat kritis sehubungan dengan pengaruhnya terhadap daya berkecambah dan viabilitas benih. Hal tersebut terjadi karena semakin lama benih disimpan akan menyebabkan terjadinya stres air yang mengakibatkan kemunduran benih (Pammenter et al., 1994;). Daya simpan atau kemampuan benih untuk disimpan ditentukan oleh kadar air awal benih. Kadar air benih untuk penyimpanan adalah sebatas kadar air kritisnya (Nurhasybi dan Suita, 2012; Yuniarti dan Djaman, 2015). Sementara itu, Halimursyadah (2012) menyebutkan bahwa kadar air di awal simpan perlu diperhatikan karena semakin rendah kadar air maka daya simpannya juga semakin rendah. Viabilitas benih di bawah kondisi penyimpanan bervariasi antar spesies yang tergantung pada berbagai faktor (Mng`omba et al., 2007). Cara praktis untuk memperpanjang umur simpan benih rekalsitran adalah dengan penyimpanan pada suhu yang lebih rendah sehingga kerusakan dapat dikurangi dan pada saat yang sama kerusakan akibat pendinginan atau pembekuan tidak terjadi (Umarani et al., 2015). Perbedaan respon beberapa spesies terhadap kondisi penyimpanan seperti dilaporkan pada buah rotan manau yang dapat disimpan baik pada suhu $10-15^{\circ} \mathrm{C}$ (Kartiko, 1987), tetapi benih ramin (Gonystylus bancanus) mengalami kerusakan pada suhu tersebut (Kartiko, 1998).

Kecepatan berkecambah (KT) benih yang langsung ditanam (tanpa penyimpanan) lebih tinggi dibandingkan setelah benih mengalami proses penyimpanan. Hal tersebut menunjukkan bahwa pada kondisi tersebut perkecambahan benih berlangsung sempurna sebagai indikator vigor benih masih baik. Vigor benih dicerminkan oleh dua informasi tentang viabilitas yaitu : "kekuatan tumbuh" dan "daya simpan" benih. Kedua nilai fisiologis ini menempatkan benih pada kemungkinan kemampuannya untuk tumbuh menjadi tanaman normal meskipun keadaan biofisik lapangan produksi suboptimum atau kondisi sesudah benih melampaui suatu periode simpan yang lama (Maemunah dan Adelina, 2009). Kecepatan berkecambah melambat dengan menurunnya daya berkecambah dan semakin lamanya waktu penyimpanan disebabkan oleh cadangan makanan dalam benih yang semakin menurun (Nurhasybi et al., 2007; Maemunah dan Adelina, 2009; Sulaiman et al., 2010) termasuk kadar air sebagai bahan dari proses metabolisme. Kecepatan berkecambah 
mempunyai kaitan yang erat dengan nilai perkecambahan. Laju perkecambahan hanya menunjukkan rata-rata hari berkecambah, sedangkan nilai perkcambahan menunjukkan jumlah benih berkecambah dalam persen per hari sampai akhir pengujian yang merupakan pencerminan dari daya tumbuh benih (Payung et al. 2012)

Selain aspek fisiologis, hasil analisis biokimia menunjukkan bahwa komposisi kandungan biokimia benih $S$. stenoptera meliputi kandungan pati, lemak dan protein cenderung mengalami peningkatan dan penurunan selama penyimpanan. Kondisi demikian juga terjadi pada penyimpanan propagul Rhizophora apiculata (Rohandi dan Widyani, 2010). Hasil analisis kandungan biokimia benih selama penyimpanan selengkapnya disajikan pada Tabel 4.

Tabel 4. Jumlah kandungan pati, lemak, protein dan Daya Hantar Listrik (DHL) pada berbagai perlakuan penyimpanan benih $S$. stenoptera

Table 4. Contain of starch, fat, protein and leachate conductivity of many storage treatments of $\mathrm{S}$. stenoptera seeds

\begin{tabular}{cccccc}
\hline No. & Perlakuan & $\begin{array}{c}\text { Pati } \\
\mathbf{( \% )}\end{array}$ & $\begin{array}{c}\text { Lemak } \\
\mathbf{( \% )}\end{array}$ & $\begin{array}{c}\text { Protein } \\
\mathbf{( \% )}\end{array}$ & $\begin{array}{c}\text { DHL } \\
\text { (milimhos) }\end{array}$ \\
\hline 1. & A1B0 & 10.09 & 15.47 & 8.63 & 0.26 \\
\hline 2. & A1B1 & 7.31 & 12.09 & 6.81 & 0.20 \\
\hline 3. & A1B2 & 5.16 & 12.37 & 6.81 & 0.35 \\
\hline 4. & A1B3 & 9.53 & 6.05 & 6.56 & 1.08 \\
\hline 5. & A1B4 & 7.44 & 22.81 & 6.88 & 0.22 \\
\hline 6. & A2B0 & 10.09 & 15.47 & 8.63 & 0.26 \\
\hline 7. & A2B1 & 5.55 & 10.83 & 6.88 & 0.14 \\
\hline 8. & A2B2 & 9.07 & 13.14 & 5.81 & 0.85 \\
\hline 9. & A2B3 & 10.25 & 20.31 & 7.88 & 0.37 \\
\hline 10 & A2B & 5.77 & 34.31 & 7.57 & \\
\hline
\end{tabular}

Sumber : diolah dari data primer

Keterangan : A : Ruang simpan (1 : ruang kamar; 2 : ruang AC), B : Lama penyimpanan (0 : tanpa penyimpanan; $1: 1$ minggu; 2 : 2 minggu; $3: 3$ minggu; $4: 4$ minggu)

Kandungan pati mengalami penurunan masing-masing 2,65\% (ruang kamar) dan 4,32\% (ruang AC). Yuniarti et al. (2013) menjelaskan bahwa penurunan karbohidrat mengindikasikan terjadinya penurunan pertahanan benih yaitu penurunan viabilitas benih yang ditandai dengan penurunan daya berkecambah benih selama penyimpanan. Nkang (1988) menjelaskan bahwa pengeringan yang berlebihan juga akan menyebabkan hilangnya karbohidrat baik karena polimerisasi atau koagulasi/pembekuan.

Sementara itu, kandungan protein benih tengkawang pada akhir penyimpanan baik ruang kamar ataupun ruang $\mathrm{AC}$ mengalami penurunan dibanding kontrol. Penurunan kadar protein benih pada ruang kamar sebesar 1,75\% lebih tinggi dibanding pada ruang $\mathrm{AC}$ sebesar 1,06\%. Kandungan protein membran mitokondria menurun lebih cepat karena protein lebih peka terhadap kondisi penyimpanan yang kurang menguntungkan. Protein membran bersama fosfolipid berfungsi menjalankan fungsi membran. Menurunnya kadar fosfolipid membran akan berpengaruh terhadap penurunan fungsi membran. Menurunnya kadar fosfolipid dan protein membran mencerminkan terjadinya kemunduran benih (Tatipata et al. 2004). Hal serupa terjadi pada pengeringan Calamus spp (Girija and Srinivasan, 1998), penurunan kadar air diikuti dengan penurunan kandungan protein dalam benih yang erat kaitannya dengan peningkatan asam amino bebas. Hartawan dan Nengsih (2012) menyebutkan bahwa penurunan kandungan karbohidrat, protein dan lemak dapat disebabkan oleh perombakan cadangan makanan akibat peningkatan proses respirasi karena tingginya kadar air benih. Shaban (2013) menyebutkan bahwa protein dalam benih disintesis sebagai 
sumber karbon, nitrogen dan sulfur untuk generasi tanaman selanjutnya.

Kandungan lemak benih tengkawang selama penyimpanan terlihat cukup bervariasi. Kandungan lemak cenderung mengalami peningkatan pada akhir pengamatan. Penurunan kadar air dan kadar lemak total serta peningkatan asam lemak bebas menyebabkan penurunan viabilitas dan vigor benih. Gejala kemunduran secara biokimia pada benih adalah perubahan dalam aktivitas enzim, laju respirasi, peningkatan asam lemak dan berkurangnya persediaan cadangan makanan. Kandungan asam lemak yang tinggi di dalam benih merupakan indikasi terjadinya akumulasi asam lemak, karena tidak diproses lebih lanjut menjadi energi sehingga benih kehilangan energi untuk berkecambah (Tresniawati et al., 2014). Peningkatan kandungan lemak diduga merupakan mekanisme pertahanan benih selama penyimpanan (Yuniarti et al., 2013). Laju kemunduran benih yang cepat disebabkan oleh tingginya kadar lemak (oily seed) terutama bila kandungan asam lemak tak jenuhnya tinggi. Proses oksidasi yang terjadi selama penyimpanan dapat menyebabkan putusnya ikatan rangkap dari asam lemak tak jenuh sehingga dapat menghasilkan radikel-radikel bebas yang dapat bereaksi dengan lipida lainnya menyebabkan rusaknya struktur membran sel. Percepatan kemunduran seperti itu terjadi pada benih berprotein (protein seed) dan benih berkarbohidrat (starchy seed) (Justice and Bass, 2002). Peningkatan asam lemak bebas dan pengurangan gula terjadi pada endosperma dan kulit benih Vatica chinensis L. selama penyimpanan (Sukesh and Chandrashekar, 2013).

Data pada Tabel 4 menunjukkan bahwa nilai kandungan lemak pada benih segar (tanpa perlakuan) $15,47 \%$. Kadar lemak benih $S$. stenoptera cukup tinggi bila dibandingkan dengan Acacia mangium yaitu 5\% (Syamsuwida et al., 2002) ataupun $R$. apiculata sebesar $0,07 \%$ (Rohandi dan Widyani, 2010). Hal tersebut menunjukkan kecenderungan benih bersifat rekalsitran. Salah satu ciri benih rekalsitran adalah tingginya kadar lemak yang dikandung, sehingga benih cepat rusak selama penyimpanan (Sudjindro, 1994).
Indikasi biokimia juga dapat dilihat dari nilai daya hantar lisrik benih tengkawang yang semakin besar dengan semakin lamanya waktu penyimpanan. Nilai daya hantar listrik akan meningkat dengan semakin menurunnya vigor benih sehingga benih tersebut cenderung akan membocorkan bahan-bahan metabolit yang dikandungnya dan kebocoran dalam membran sel merupakan tempat kerusakan yang nyata dari kemunduran benih (AOSA, 1983; Mugnisjah et al., 1994; Manju and Kumar, 2015). Sifat zat terlarut yang dialiri arus listrik banyak mengandung kalium, gula dan asam amino yang memberikan kontribusi untuk perkecambahan benih. Selama proses imbibisi terjadi kehilangan zat terlarut dari benih akibat gangguan konstruksi membran atau kerusakan sel yang sangat mengurangi potensi perkecambahan benih untuk tumbuh menjadi bibit yang sehat (Manju and Kumar, 2015). Oleh sebab itu, daya hantar listrik dapat dijadikan sebagai indikator viabilitas benih (Ramos et al., 2012).

Terjadinya kebocoran membran juga berhubungan dengan transisi fase lemak (lipid phase transition). Fosfolipid membran terjadi dalam dua fase yaitu fase kristal cair (liquid crystalline phase) dan fase gel (gel phase). Peningkatan suhu dalam pengeringan mengakibatkan perubahan fase kristal cair pada membran fosfolipid menjadi fase gel, yang menghasilkan peningkatan kebocoran membran selama pengeringan atau reimbibisi (Kraak, 1993 dalam Adimargono, 1997). Hal tersebut merupakan salah satu penyebab terjadinya peningkatan nilai daya hantar listrik dalam benih. Neto et al. (2014) menjelaskan bahwa selain kadar air awal benih, faktor yang berpengaruh terhadap kecepatan pelarutan elektrolit dari dalam benih adalah asal benih, kulit benih, suhu imbibisi dan kualitas awal benih.

Beberapa penelitian daya hantar listrik untuk mendeteksi kualitas fisiologis benih tanaman kehutanan antara lain Pinus taeda L., $P$. Eliotti Engelm, $P$. pasutris Mill, $P$. Echinata Mill, P. strobus L (Bonner, 1991), E. cyclocarpum dan Paraserianthes falcataria (Nugroho, 1998), Gmelina arborea (Siskasari, 2001), R. apiculata (Rohandi dan Widyani, 2010), Garcinia kola Heckel (Asomaning et al., 2011), Vatica chinensis L. (Sukesh and 
Chandrashekar, 2013) serta Caesalpinia echinata Lam. (Neto et al., 2014).

\section{KESIMPULAN}

Interaksi antara ruang simpan dan periode penyimpanan berpengaruh sangat nyata terhadap daya berkecambah (DB) dan kecepatan berkecambah (KT) benih tengkawang, tetapi tidak berpengaruh nyata terhadap parameter kadar air (KA) dan nilai perkecambahan (NP) yang hanya dipengaruhi oleh faktor periode penyimpanan. Viabilitas benih terus menurun dengan semakin lamanya periode penyimpanan. Selama empat minggu, daya berkecambah benih (KA awal 46,06\%) di ruang kamar mampu dipertahankan sebesar 44\% dan di ruang AC sebesar 49,33\%. Kandungan lemak dan nilai daya hantar listrik cenderung mengalami peningkatan, sedangkan kandungan pati dan protein pada benih tengkawang cenderung mengalami penurunan selama penyimpanan.

\section{UCAPAN TERIMA KASIH}

Ucapan terima kasih penulis sampaikan kepada Balai Penelitian Teknologi Perbenihan Tanaman Hutan Bogor yang telah memberikan dana dan fasilitas untuk menyelesaikan kegiatan penelitian ini. Selain itu, ucapan terimakasih penulis sampaikan kepada Sdri. Enok R. Kartiana dan Sdr. Dwi Haryadi serta semua pihak yang telah memberikan bantuan teknis sehingga penelitian ini dapat terlaksana dengan baik.

\section{DAFTAR PUSTAKA}

Adimargono, S. (1997). Recalcitrant seeds, identification and storage. Thesis. Larenstein International Agriculture College, Deventer.

AOSA. (1983). Seed Vigor Testing Handbook Prepared By Seed Vigor Test Committee of The Association of Official Seed Analysis. Contribution No $32.88 \mathrm{p}$

Asomaning, J.M., N. S. Olympio \& M. Sacande. (2011). Desiccation Sensitivity and Germination of Recalcitrant Garcinia kola Heckel Seeds. Research Journal of Seed Science : 1-13.

Bonner (1991). Estimating Seed Quality of Southern Pines by Leachate Conductivity. United States Departement of Agriculture. New Orleans, Louisiana.

Djaman, D.F., D. Priadi dan E. Sudarmonowati. (2006). Penyimpanan Benih Damar (Agathis damara
Salisb.) dalam Nitrogen Cair . Biodiversitas. 7 (2) : 164-167

Girija, T. and S. Srinivasan. (1998). Metabolic Changes Associated with Dessication in Calamus Seeds. IUFRO Seed Symposium Recalcitrant Seeds 12 - 15 October 1998. Kualalumpur. Malaysia.

ISTA. (1985). Seed Science and Technology. 13. Zurich, Switzerland.

(2006). International Rules for Seed Testing. The International Seed Testing Association (ISTA) P.O. Box 308, 8303 Bassersdorf, $\mathrm{CH}-$ Switzerland.

Halimursyadah. (2012). Pengaruh Kondisi Simpan Terhadap Viabilitas dan Vigor Benih Avicennia marina (Forsk.)Vierh. Pada Beberapa Periode Simpan. Jurnal Agrotropika 17 (2): 43-51,

Hartawan, R. dan Y. Nengsih. (2012). Karbohidrat dan Kadar Air Berperan Penting Dalam Mempertahankan Kualitas Benih Karet. Agrivigor 5 (2): 103-111

Istomo dan Hidayati. (2010). Studi Potensi dan Penyebaran Tengkawang (Shorea spp.) di Areal IUPHHK-HA PT. Intracawood Manufacturing Tarakan, Kalimantan Timur. Jurnal Silvikultur Tropika 1 (1) : $11-17$

Justice, O. L. dan Louis, N. Bass. (2002). Prinsip dan Praktek Penyimpanan Benih. Rajawali Pers.

Kartiko, H.D.P. 1987. Suhu dan Lama Pengeringan untuk Penyimpanan Benih Rotan Manau (Calamus manan MIQ). Buletin Teknologi Perbenihan. Bogor.

(1998). Teknik Penyimpanan Sederhana Benih Cepat Rusak dari Tanaman Langka : Ramin (Gonystylus bancanus Kurtz). Buletin Teknologi Perbenihan 5 (2) : 1-8. Bogor.

Khrisnan, P., S. Nagarajan \& A.V. Moharir. (2005). Biophysical Characteristation of Seed Water Status and Its Relationship with Seed Water Status. Proc. Indian Natl. Sci. Acad, 71 (3) : 163179.

Lodong, O., Y. Tambing dan Adrianton. (2015). Peranan Kemasan dan Media Simpan Terhadap Ketahanan Viabilitas Dan Vigor Benih Nangka (Artocarpus heterophyllus Lamk) Kultivar Tulo5 Selama Penyimpanan. e-J. Agrotekbis 3 (3) : $303-315$.

Maemunah dan E. Adelina. (2009). Lama Penyimpanan dan Invigorasi Terhadap Vigor Bibit Kakao (Theobroma cacao L.). Media Litbang Sulteng 2 (1) : $56-61$.

Mahjabin, S. Bilal and A.B. Abidi. (2015). Physiological and Biochemical Changes During Seed Deterioration: A Review. International Journal of Recent Scientific Research, 6 (4) : 3416-3422.

Martawijaya, A., I. Kartasujana, K. Kadir dan S. A. Prawira. (1981). Atlas Kayu Indonesia Jilid I. Pusat Penelitian dan Pengembangan Kehutanan. Direktur Jendral Kehutanan.

Manju, V. \& S. Kumar. (2015). Seed Leachate Conductivity and its Correlation With The Seed Viability and Germination of Tnau Papaya Cv. 
Co8 Seeds Stored Under Different Environmental Conditions. International Journal of Agricultural Science and Research (IJASR), 5 (4) : 127-130.

Mng'omba, S.A., Toit, E.S., \& Akinnifesi, F.K. (2007). Germination Characteristics of Tree Seeds: Spotlight on Southern African Tree Species. Tree and Forestry Science and Biotechnology 1(1) : 18.

Mugnisjah, W. Q., A. Setiawan, C. Santiwa dan Suwarto. (1994). Panduan Praktikum dan Penelitian Bidang Ilmu dan Teknologi Benih. PT. Raja Grafindo Persada. Jakarta.

Neto, N.M., E.V. Lamarca, \& C.J. Barbedo. (2014). Kinetics of solute leachate from imbibing Caesalpinia echinata Lam. (Brazilwood) seeds. Rev. Ceres, Viçosa, 61 (1) : 090-097.

Nkang, A. (1988). Some Aspects of Biochemical Basis of Viability Loss in Stored Guilfoxylia monostylis Seeds. Seed Science and Technology 16: 247-260.

Nugroho, A. A. (1998). Pendugaan Kualitas Benih Sengon Buto (Enterolobium cyclocarpum Griseb) dan Sengon Laut (Paraserianthes falcataria (L) Nielsen) Berdasarkan Uji Daya Hantar Listrik. Skripsi. Jurusan Manajemen Hutan IPB. Bogor.

Nurhasybi, D. J. Sudrajat dan N. Widyani. (2007). Pengaruh Pengeringan dan Kondisi Penyimpanan Terhadap Daya Berkecambah Benih Meranti Merah (Shorea leprosula). Jurnal Penelitian Hutan Tanaman 4 (1). Puslitbang Hutan Tanaman. Badan Litbang Kehutanan. Bogor.

Nurhasybi , Suita E. (2012). Perkecambahan dan Vigor benih Suren (Toona sureni (Blume) Merr.) Pada Berbagai Metode Perkecambahan dan Pengeringan. Prosiding Seminar Hasil-Hasil Penelitian "Teknologi Perbenihan Jenis-Jenis Potensial untuk Rehabilitasi Lahan Bekas Tambang di Provinsi Kepulauan Bangka Belitung." 3 Oktober 2012. Balai Penelitian Teknologi Perbenihan Tanaman Hutan. Pangkal Pinang.

Pammenter, N.W. (1994). Why Do Stored Hydrated Recalcitrant Seeds Die?. Seed Science. Research 4: 187-191.

Payung, D., E. Prihatiningtyas dan S. H. Nisa. (2012). Uji Daya Kecambah Benih Sengon (Paraserianthes falcataria (L.) Nielsen) di Green House. Jurnal Hutan Tropis, 13 (2) : 133-138

Purwaningsih. (1999). Pengaruh Kondisi Ruang Simpan, Lama Penyimpanan dan Invigorasi Terhadap Viabilitas Benih Tengkawang Tungkul (Shorea stenoptera BURCK). Tesis. Institut Pertanian Bogor. Bogor. Tidak diterbitkan.

Ramos, K.M.O., J.M.M.Matos, R..C.C.Martins, \& I.S. Martins. (2012). Electrical Conductivity Testing as Applied to the Assessment of Freshly Collected Kielmeyera coriacea Mart. Seeds. International Scholarly Research Network (ISRN) Agronomy : 1-5.
Rohandi, A dan N. Widyani. (2010). Dampak Penurunan Kadar Air Terhadap Respon Fisiologis dan Biokimia Propagul Rhizophora apiculata BI. Jurnal Penelitian Hutan Tanaman 7 (4) : 170-179.

Rohandi, A dan N. Widyani. (2011). Analisis Perubahan Fisiologi dan Biokimia Benih Tengkawang Selama Pengeringan. Jurnal Penelitian Hutan Tanaman 8 (1). Pusat Penelitian dan Pengembangan Peningkatan Produktivitas Hutan. Bogor.

Siskasari, E. (2001). Studi Pendugaan Viabilitas Benih Gmelina (Gmelina arborea Linn) Berdasarkan Uji Daya Hantar Listrik. Skripsi. Fakultas Pertanian. Institut Pertanian Bogor. Bogor. 32 Hal.

Shaban, M. (2013). Biochemical aspects of protein changes in seed physiology and germination. International Journal of Advanced Biological and Biomedical Research, 1 (8) : 885-898.

Sudjindro. (1994). Indikasi Kemunduran Viabilitas Oleh Dampak Guncangan Pada Benih Kenaf (Hibiscus cannabinus L.). Disertasi Program Pasca Sarjana. IPB.

Sulaiman, F., M. U. Harun dan A. Kurniawan. (2010). Perkecambahan Benih Tanaman Karet (Hevea Brasiliensis Muell. Arg.). Yang Disimpan Pada Suhu dan Periode Yang Berbeda. Prosiding Seminar Nasional, 13-14 Desember 2010 : 15931603. Palembang.

Sukesh \& K.R. Chandrashekar. (2013). Effect of Temperature on Viability and Biochemical Changes During Storage of Recalcitarant Seeds of Vatica chinensis L. International Journal of Botany, 9 (3) : 73-79.

Sutopo, L. (2002). Teknologi Benih edisi revisi. Fakultas Pertanian Universitas Brawijaya. PT. Raja Grafindo Persada. Malang.

Syamsuwida, D; N. Yuniarti; E.R. Kartiana, A. Muharam dan E. Ismiati. (2002). Biokimia Benih: Kemunduran benih yang disebabkan oleh perubahan fisiologi dan biokimia benih orthodok. LHP No. 375. BPPTP. Bogor.

Tatipata, A, P. Yudono, A. Purwantoro dan W. Mangoendidjojo. (2004). Kajian Aspek Fisiologi dan Biokimia Deteriorasi Benih Kedelai Dalam Penyimpanan. Jurnal Ilmu Pertanian 11 (2) : 7687.

Tresniawati, C., E. Murniati dan E. Widajati. (2014). Perubahan Fisik, Fisiologi dan Biokimia Selama Pemasakan Benih dan Studi Rekalsitransi Benih Kemiri Sunan. J. Agron. Indonesia 42 (1) : $74-$ 79.

Umarani, R., E. K. Aadhavan and M. Faisal. (2015). Understanding Poor Storage Potential of Recalcitrant Seeds, Current Science, 108 (11) : 2023-2034.

Yuniarti, N. D. Syamsuwida, A. R. Hidayat dan E. Ismiati. (2005). Laju Kemunduran Benih Ditinjau Dari Perubahan Fisiologi dan Biokimia Benih Orthodok. Laporan Hasil Penelitian. BPPTP. Bogor. 
Yuniarti, N. D. Syamsuwida dan A. Aminah. (2013). Dampak Perubahan Fisiologi dan Biokimia Benih Eboni (Diospyros celebica Bakh.) Selama Penyimpanan. Jurnal Penelitian Hutan Tanaman $10(2): 65-71$.

Yuniarti, N. dan D.F. Djaman. (2015), Teknik pengemasan yang tepat untuk mempertahankan viabilitas benih bakau (Rhizophora apiculata) selama penyimpanan. Prosiding Seminar Nasional Masyarakat Biodiversitas Indonesia 1 (6) : 1438-1441

Zanzibar, M. (2011). Efektivitas Perlakuan Primming dan Pendugaan Mutu Fisiologis Secara Cepat Pada Benih Tusam (Pinus merkusii Jungh et de Vriese). Jurnal Standarisasi, 13(1): 90-97. 
JURNAL Penelitian Ekosistem Dipterokarpa Vol. 2 No. 1, Juli 2016 Hal. 9-20

P-ISSN: 2460-5875 | E-ISSN: 2460-5883 